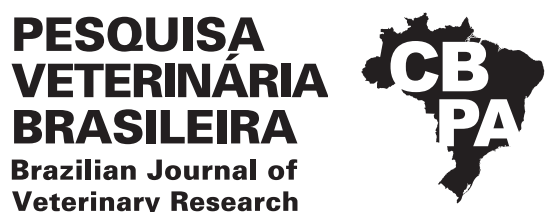

Pesq. Vet. Bras. 41:e06912, 2021

DOI: 10.1590/1678-5150-PVB-6912

Original Article

inarv Research

Livestock Diseases

ISSN 0100-736X (Print)

(cc) BY-NC

\title{
Clinical findings of equine leukoencephalomalacia ${ }^{1}$
}

\author{
Lukas G. Albertino ${ }^{2}$ (D) Natália M. Dias² ${ }^{2}$ Juliana J. Moreira² ${ }^{2}$ José P. Oliveira-Filho ${ }^{2}$ (D), \\ Regina K. Takahira², Renée Laufer-Amorim ${ }^{2}$ (D) , Alexandre S. Borges ${ }^{2}$ \\ and Rogério M. Amorim²*
}

\begin{abstract}
Albertino L.G., Dias N.M., Moreira J.J., Oliveira-Filho J.P., Takahira R.K., Laufer-Amorim R., Borges A.S. \& Amorim R.M. 2021. Clinical findings of equine leukoencephalomalacia. Pesquisa Veterinária Brasileira 41:e06912, 2021. Departamento de Clínica Veterinária, Faculdade de Medicina e Zootecnia, Universidade Estadual Paulista "Júlio de Mesquita Filho", Rua Prof. Doutor Walter Mauricio Correa s/n, Cx. Postal 560, Botucatu, SP 18618-681, Brazil E-mail: rogerio.amorim@unesp.br

Equine leukoencephalomalacia (LEM) is a disease caused by the ingestion of food, especially corn, contaminated by fumonisin, a Fusarium verticillioides (synonymous with $F$. moniliforme) metabolite. The clinical signs of brain injuries have an acute onset and rapid evolution. This study aimed to describe the clinical findings in 11 animals diagnosed with LEM, including cerebrospinal fluid (CSF) analysis. Of these animals, 91\% (10/11) were horses, and only $9 \%(1 / 11)$ were asinine. The clinical localization of the lesions was $64 \%(7 / 10)$ cerebral, manifested mainly by altered mental state and behavioral disturbance, and 36\% (4/11) were brainstem lesions, manifested by incoordination, head tilt, nystagmus, facial hypoalgesia, difficulty in apprehension, chewing, and swallowing food. Postmortem findings revealed that $82 \%(9 / 11)$ of the lesions were in the cerebrum and $18 \%(2 / 11)$ in the brainstem. CSF findings, such as xanthochromia (43\%, 3/7), hyperproteinorrachia $(50 \%, 3 / 6)$, and pleocytosis $(43 \%, 3 / 7)$ were observed. The affected animals showed neurological signs that were compatible with cerebral and/or brainstem injuries. The CSF from animals with LEM may present with xanthochromia, hyperproteinorrachia, and pleocytosis, reinforcing the fact that this disease should be included in the differential diagnosis of encephalomyelopathies.
\end{abstract}

INDEX TERMS: Leukoencephalomalacia, equine, epidemiological aspects, clinical aspects.

RESUMO.- [Achados clínicos de leucoencefalomalácia equina.] A leucoencefalomalácia (LEM) é uma enfermidade que acomete equídeos causada pela ingestão de milho e seus derivados e feno contaminados pela micotoxina fumonisina, um metabólito do fungo Fusarium verticillioides (sinônimo para F. moniliforme). Os sinais clínicos apresentam início agudo e evolução rápida e são decorrentes de lesões encefálicas. 0 objetivo deste estudo é descrever os achados clínicos de 11 equídeos diagnosticados com LEM, incluindo a análise do líquido cefalorraquidiano (LCR). 91\% dos animais afetados eram equinos e somente $9 \%(1 / 11)$ era asinino. A localização clínica das lesões era $64 \%(7 / 10)$ cerebrais, manifestadas por alterações no estado mental e comportamento e $36 \%$ (4/10) no tronco encefálico,

\footnotetext{
${ }^{1}$ Received on June 2, 2021.

Accepted for publication on August 9, 2021.

${ }^{2}$ Departamento de Clínica Veterinária (DCV), Faculdade de Medicina e Zootecnia (FMVZ), Universidade Estadual Paulista "Júlio de Mesquita Filho" (Unesp), Rua Prof. Doutor Walter Mauricio Corrêa s/n, Cx. Postal 560, Botucatu, SP 18618-681, Brazil. *Corresponding author: rogerio.amorim@unesp.br
}

manifestadas por incoordenação, desvio lateral de cabeça, nistagmo, hipoalgesia da face e dificuldade de apreensão, mastigação e deglutição de alimentos. Comparativamente, os achados post mortem revelaram que $82 \%$ (9/11) das lesões eram no cérebro e 18\% (2/11) no tronco encefálico. Alteraç̃oes no LCR, tais como xantocromia $(43 \%, 3 / 7)$, hiperproteinorraquia $(50 \%, 3 / 6)$ e pleocitose $(43 \%, 3 / 7)$, foram observadas. Os animais afetados apresentaram sinais clínicos compatíveis com lesões encefálicas e/ou de tronco cerebral. O LCR de animais com LEM pode apresentar xantocromia, hiperproteinorraquia, e pleocitose, reforçando que esta doença deve ser incluída como diagnóstico diferencial de encefalomielites.

TERMOS DE INDEXAÇÃO: Leucoencefalomalácia, equinos, aspectos epidemiológicos, aspectos clínicos.

\section{INTRODUCTION}

Leukoencephalomalacia (LEM) is a disease caused by the ingestion of corn and its derivatives, such as pelleted feeds and 
hay (Vendruscolo et al. 2016) contaminated with fumonisin, a Fusarium verticillioides metabolite (synonymous with $F$. moniliforme) (Câmara et al. 2008, Del Fava et al. 2010, RietCorrea et al. 2013). In the south and southeast of Brazil, this disease is seasonal, occurring mainly from July to September (Salles-Gomes et al. 2003, Riet-Correa et al. 2013, Reis-Gomes et al. 2018). The disease affects equines, and there are few reports in the literature on its occurrence in asinine, which is considered a species with possible resistance to the disease (Salles-Gomes et al. 2003, Riet-Correa et al. 2013, Reis-Gomes et al. 2018). LEM is caused by B1 (FB1), B2 (FB2), A1 (FA1), and A2 (FA2) fumonisins (Câmara et al. 2008). However, FB1 is considered to play a key role in the clinical and pathological manifestations of the disease (Mallmann et al. 1999, StockmannJuvala \& Savolainen 2008, Mackay \& Van Metre 2015).

Fumonisins are structurally similar to the precursors of sphingolipids, a lipid class present in the cell membranes of all eukaryotic cells, which play a role in cellular regulation. In mammalian cells, the main precursors are sphinganine (Sa) and sphingosine (So). Fumonisins inhibit the role of the enzyme ceramide synthase, a key enzyme in the biosynthesis of new long-chain sphingolipids, leading to intracellular accumulation of bioactive intermediates and cellular oxidative stress. In addition, they alter cell proliferation, communication, apoptosis, and gene modulation. The toxicity of fumonisins mainly affects the liver and kidneys of animals. Due to their cellular modifying ability, these mycotoxins were considered carcinogenic by the International Agency for Research on Cancer (IARC) (Minami et al. 2004, Bando et al. 2007, Stockmann-Juvala \& Savolainen 2008).

The onset of clinical signs is acute, with rapid evolution within 2 to 72 hours and death between 6 to 24 hours after the first clinical manifestation (Riet-Correa et al. 1998, Pimentel et al. 2009, Del Fava et al. 2010, Santos et al. 2013, Vendruscolo et al. 2016). In horses, cerebral signs are common, while in donkeys, brainstem signs are predominant (Del Fava et al. 2010). There is no specific treatment for LEM, and in most cases, the affected animals either die or are euthanized due to neurological sequelae (Mackay \& Van Metre 2015).

Hematological analysis showed that the packed cell volume increased due to dehydration, as well as neutrophilia and eosinophilia. Serum biochemistry showed elevated levels of liver enzymes, such as alkaline phosphatase (ALP), aspartate aminotransferase (AST), and gamma-glutamyltransferase (GGT). This indicates the presence of hepatic lesions (Câmara et al. 2008, Mackay \& Van Metre 2015). The cerebrospinal fluid (CSF) findings reported in horses affected by LEM demonstrate the presence of hyperproteinorrachia (Mackay \& Van Metre 2015). Definitive diagnosis is possible through mycotoxicology analysis of the food given to the animals and necropsy findings (Riet-Correa et al. 1998, Pimentel et al. 2009, Riet-Correa et al. 2013, Mackay \& Van Metre 2015).

Several studies have focused on the epidemiology, clinical signs, and pathological findings of LEM (Riet-Correa et al. 1998, Mallmann et al. 1999, Salles-Gomes et al. 2003, Câmara et al. 2008, Pimentel et al. 2009, Del Fava et al. 2010, Riet-Correa et al. 2013, Vendruscolo et al. 2016, Reis-Gomes et al. 2018). However, few studies have focused on the findings in the CSF of affected animals. This study aimed to describe the clinical findings of equines affected by LEM, including CSF analysis.

\section{MATERIALS AND METHODS}

Study local and contextualization. The clinical records, from 1996 to 2019, of equids clinically suspected with LEM at the Large Animal Hospital of the "Faculdade de Medicina e Zootecnia", "Universidade Estadual Paulista Júlio de Mesquita Filho" (FMVZ-Unesp), Botucatu, São Paulo, were assessed. Cases were included in the present study based on the following criteria: post mortem LEM diagnosis, based on macro and/or histopathological findings; and/or the detection of fumonisins through high-performance liquid chromatography (HPLC) in the food offered to the animals. In addition, all animals included in this study were tested negative for rabies.

Epidemiological and clinical data. The epidemiological aspects included species (horses, asinine, and mules), breed, sex, age, season of the year, and animal food containing toxins. The clinical aspects (time of disease evolution, physical and laboratory examination results, treatment, and outcome) were based on the findings presented by the veterinarians in the medical records. Complete blood cell count and serum biochemistry, and necropsy and microscopic examinations were routinely performed at "Laboratório Clínico Veterinário" and "Laboratório de Patologia Veterinária" of the FVMZ-Unesp, using hematoxylin and eosin (HE) staining.

Samples collection. CSF samples were obtained from the animals under general anesthesia using a sterile spinal needle $(0,9 \times 120 \mathrm{~mm})$ inserted into the atlanto-occipital space. CSF samples were placed in three sterile tubes and immediately submitted for laboratory analysis. CSF protein levels were determined using a specific biochemical kit (Bioprot U/LCR ${ }^{\mathrm{TM}}$ - Bioclin). The cell count was performed in a Neubauer chamber with subsequent cytocentrifugation for differential analysis. Blood count analysis was performed using a pocH-100iV Diff ${ }^{\mathrm{TM}}$ - Sysmex and serum biochemistry (Cobas Mira Plus $^{\mathrm{TM}}$, Hemotech) according to the manufacturer's instructions. All the data obtained were analyzed descriptively.

\section{RESULTS}

\section{Animals and epidemiological data}

Eleven equids diagnosed with LEM met the criteria and were evaluated in this study. Among them, $19 \%$ (2/11) were the Mangalarga breed, $19 \%$ (2/11) were miniature horses, $28 \%(3 / 11)$ were quarter horses, $28 \%(3 / 11)$ were mixed breed, and $6 \%(1 / 11)$ were miniature donkeys. $27 \%$ (3/11) of animals were male, aged between 8 and 9 years, and $73 \%$ $(8 / 11)$ were female, aged between 1 and 18 years (Table 1$)$. The time of disease evolution before being admitted to the veterinary hospital ranged from 1 to 4 days (average: 2.5 days). The time of disease evolution from the arrival at the veterinary hospital until death was from 1 to 16 days (average: 8.5 days). The percentage of cases that occurred in spring (September to December) was 28\% (3/11) whereas 28\% (3/11) of cases occurred in autumn (March to June), and 44\% (5/11) occurred in winter (June to September).

\section{Clinical signs and post mortem findings}

At the initial physical examination, the mean values of heart rate, respiratory rate, and rectal temperature were 68 bpm (beats per minute), $46 \mathrm{mpm}$ (movements per minute), and $37.9^{\circ} \mathrm{C}\left(100.22^{\circ} \mathrm{F}\right)$, respectively. Dehydration varied from $5 \%$ to $10 \%, 35 \%(3 / 10)$ of the animals had congestive/ hyperemic mucous membranes, $35 \%$ (3/10) had pink mucous membranes, $20 \%(2 / 10)$ had icteric mucous membranes, and $10 \%(1 / 10)$ of them had pale mucous membranes. Lateral 
recumbency was observed in $28 \%(3 / 11)$ of the animals while $72 \%(8 / 11)$ could stand upright. Equine 10 died after arrival at the hospital, and thus, no physical examination was performed.

The affected animals showed altered mental states and behavioral disturbances. Among the altered mental states, $55 \%(6 / 11)$ were apathetic, $18 \%(2 / 11)$ presented with hyperexcitability, $18 \%(2 / 11)$ presented a semicomatose mental state. One animal $(9 \% ; 1 / 11)$ was alert with no altered mental state (Table 1). Among behavioral disturbances, $40 \%$ $(4 / 10)$ of the animals had compulsive walking, $80 \%(8 / 10)$ had incoordination, characterized by ataxia and paresis, $10 \%(1 / 10)$ had compulsive movements, that is, pedaling movements, $10 \%(1 / 10)$ had focal seizures, $30 \%(3 / 10)$ had head pressing, 10\% (1/10) had head tilt, 60\% (6/10) bilateral blindness, 30\% (3/10) fasciculations, 30\% (3/10) ptosis (eyelid, lip, and ear), 40\% (4/10) facial hypoalgesia, 20\% $(2 / 10)$ difficulty in apprehension, chewing, and swallowing food, and 30\% (1/10) had nystagmus (Fig.1-4).

According to the neurological examination, the clinical localization of the brain lesions was $64 \%(7 / 10)$ in the cerebrum, manifested by altered mental state, behavioral disturbance, and compulsive walking and movements whereas $36 \%(4 / 10)$ lesions were in the brainstem, manifested by incoordination, head tilt, nystagmus, facial hypoalgesia, and difficulty in apprehension, chewing, and swallowing food. Postmortem findings revealed that $82 \%$ (9/11) of the lesions were in the cerebrum and $18 \%(2 / 11)$ in the brainstem.

Eighty-one percent (9/11) of the animals died. Sixty-four percent $(7 / 11)$ were diagnosed with macroscopic lesions, characterized by liquefaction necrosis of the white matter, areas of softening, especially in the cerebrum, hemorrhages, and areas of discoloration (Fig.5-7). Approximately 18\% (2/11) were diagnosed with microscopic lesions, such as swollen astrocytes and oligodendrocytes containing eosinophilic intracytoplasmic globules, eccentric hyperchromatic nuclei, and diffuse necrosis. In all the assessed cases, liver postmortem findings were characterized by congestion; autolysis; pale, dark, or gray areas; degeneration; and edema.

Two cases $(2 / 11 ; 18 \%)$ survived because of the supporting treatment and were diagnosed by mycotoxicological analysis of the feed. These animals were from the same propriety, where two other mares died after presenting similar clinical signs, and ten other horses presented eyelid and lip ptosis and were apathetic. The propriety also had two donkeys, which were clinically healthy. All the animals (14 horses and two donkeys) consumed the same contaminated feed, but only the two cases were admitted to the hospital.

\section{Food and mycotoxicological analysis}

Fifty-five percent $(6 / 11)$ of the animals in this study received foods such as cracked corn, 55\% (6/11) received pelleted feed, and 9\% (1/11) corn silage. All animals received at least two different types of feed. Mycotoxicological analysis of the food offered to five animals affected by the disease was performed, in which two animals (Equine 7 and 8) consumed the same food (Fig.8). No values for FB2 were found in the analysis of the food offered to Equine 5.

\section{Clinical pathology findings}

Serum biochemistry revealed elevated enzyme activity for AST in 75\% (6/8) of cases, ALP in 87.5\% (7/8), and GGT in $85.7 \%(6 / 7)$, as well as elevated concentrations of urea and creatinine in $37.5 \%(3 / 8)$ and $37.5 \%(3 / 8)$ of the cases, respectively.

The CSF findings revealed xanthochromia in 43\% (3/7) cases, turbidity in $14 \%(1 / 7)$, hyperproteinorrachia in $50 \%$ $(3 / 6)$, and mixed pleocytosis in 43\% (3/7). Three samples $(43 \% ; 3 / 7)$ were colorless and clear and were according to the species values for protein and cellularity.

No alterations were observed in the complete blood cell count of the animals. Serum biochemistry and CSF findings are described in Table 2.

\section{DISCUSSION}

Seventy-two percent (8/11) of the cases described in this study occurred during the autumn and winter seasons in the Southern Hemisphere (March to September). The same was observed by Riet-Correa et al. (2013) and Reis-Gomes et al. (2018). During these seasons, the pastures offered to the animals are of low quality. In addition, there are variations in temperature and humidity in the air throughout the day during these seasons, leading to food supplementation with corn and/or its derivatives; favoring the occurrence of the disease. However, some animals receive supplementation throughout the year, which explains the occurrence of the disease during the spring season (28\%; 3/11; September to March).

Table 1. Identification and neurological clinical signs of the affected animals by leukoencephalomalacia (n=11), in Botucatu/SP, 2019

\begin{tabular}{lcccl}
\hline Identification & Breed & Sex & Age & \multicolumn{1}{c}{ Clinical signs } \\
\hline Equine 1 & Mixed breed & F & 17 years & Mental state depressed, compulsive walking, incoordination and ptosis \\
Equine 2 & Mangalarga & F & 5 years & Head tilt, decrease or loss of face sensibility and incoordination \\
Equine 3 & Quarter horse & M & 9 years & Hyperexcitability, compulsive walking, incoordination and fasciculations \\
Equine 4 & Quarter horse & F & 3.6 years & Mental state depressed, bilateral blindness, head pressing and focal convulsions \\
Equine 5 & Miniature horse & M & 8 months & Semi-comatose state, bilateral blindness, incoordination and nystagmus \\
Equine 6 & Miniature horse & F & 1.6 years & Semi-comatose state, incoordination, bilateral blindness, focal convulsions and nystagmus \\
Equine 7 & Mixed breed & F & 18 years & Mental state depressed, focal convulsions, decrease or loss of face sensibility, ptosis and incoordination \\
Equine 8 & Mixed breed & M & 6 years & Mental state depressed, incoordination, difficulty of gripping, chewing and swallowing food and ptosis \\
Equine 9 & Miniature & F & 5 years & Mental state depressed, incoordination, compulsive walking, decrease or loss of face sensibility, \\
& donkey & & & difficulty of gripping, chewing and swallowing food and nystagmus \\
Equine 10 & Quarter horse & F & 1.8 years & Not performed \\
Equine 11 & Mangalarga & F & 4 years & Hyperexcitability, head pressing, incoordination, nystagmus and bilateral blindness
\end{tabular}



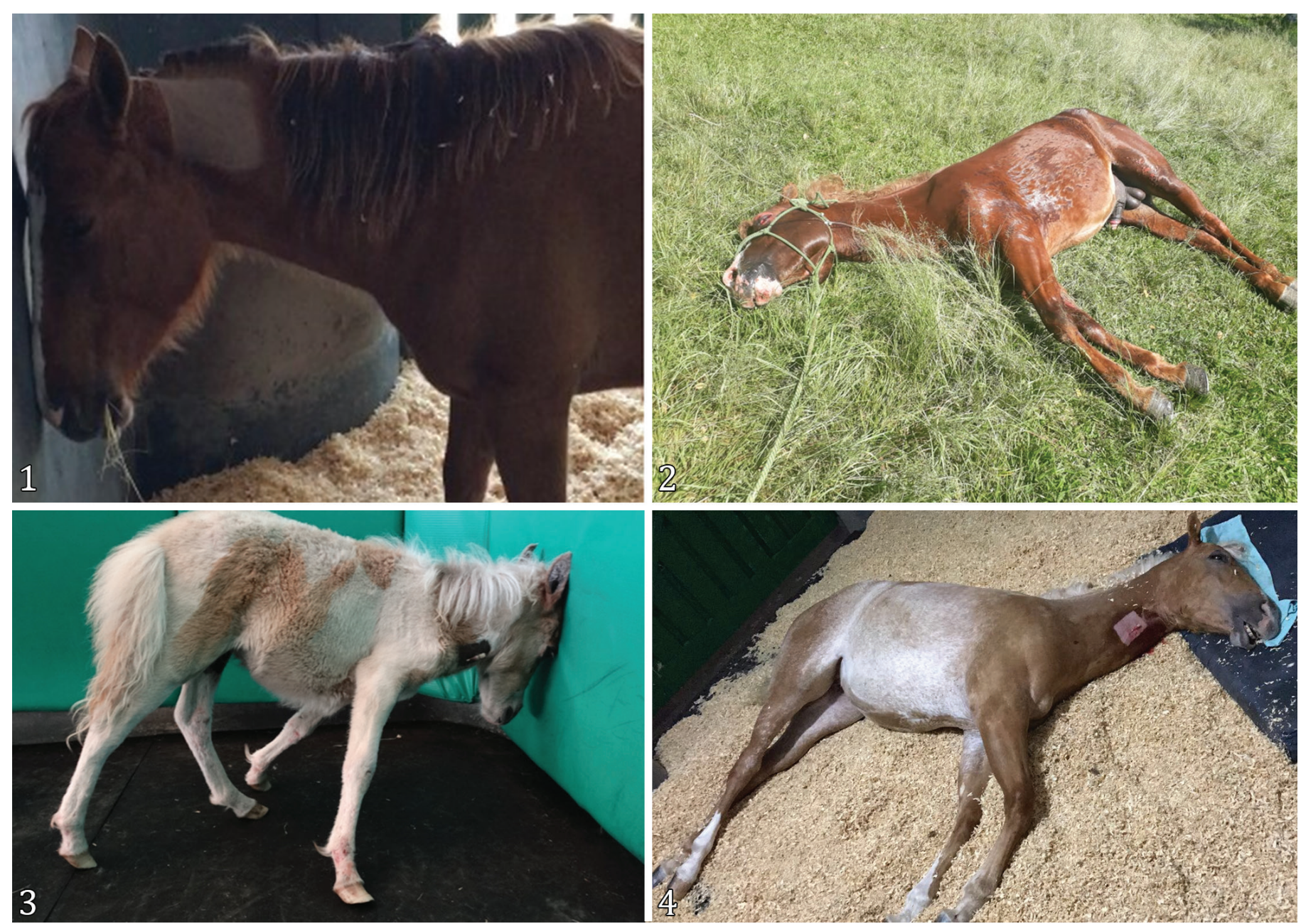
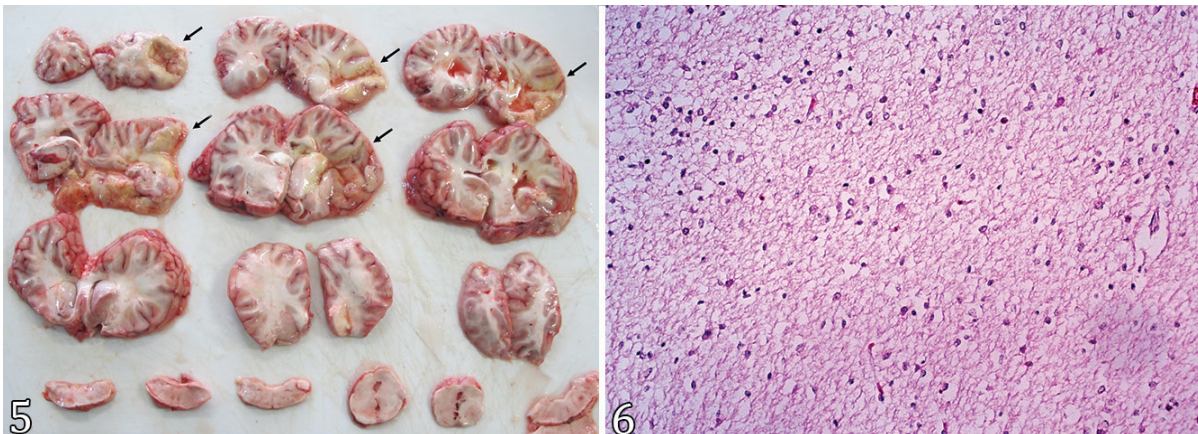

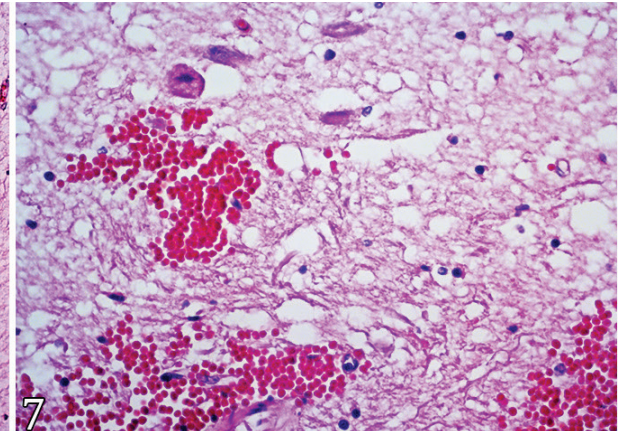

Fig.1-4. Clinical presentation of animals affected by leukoencephalomalacia.

(1-2) Horses presenting head pressing. (3-4) Horses presenting semicomatose mental state and lateral recumbency. Botucatu/SP, 2019.

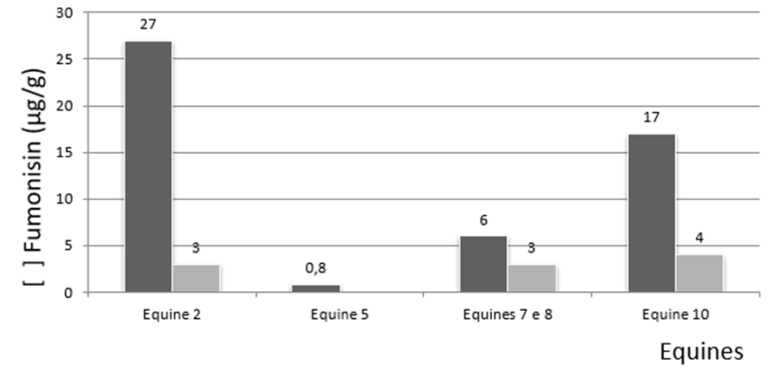

Fig.5-7. Macroscopic and microscopic alterations observed in the central nervous system of the animals affected by leukoencephalomalacia. (5) Gross image of an equine brain affected by leukoencephalomalacia with hemispheres asymmetry (arrow). (6) Microscopic image of white matter malacia with moderate glial cells and vascular congestion. Cortex. HE, obj.40x. (7) Microscopic image of white matter necrosis and mild hemorrhage. Brainstem. HE, obj.40x. Botucatu/SP, 2019.

Fig.8. Mycotoxicological analysis by HPLC technique of the contaminated feed offered to five horses affected by leukoencephalomalacia $(\mathrm{n}=5)$. Botucatu/SP, 2019. 


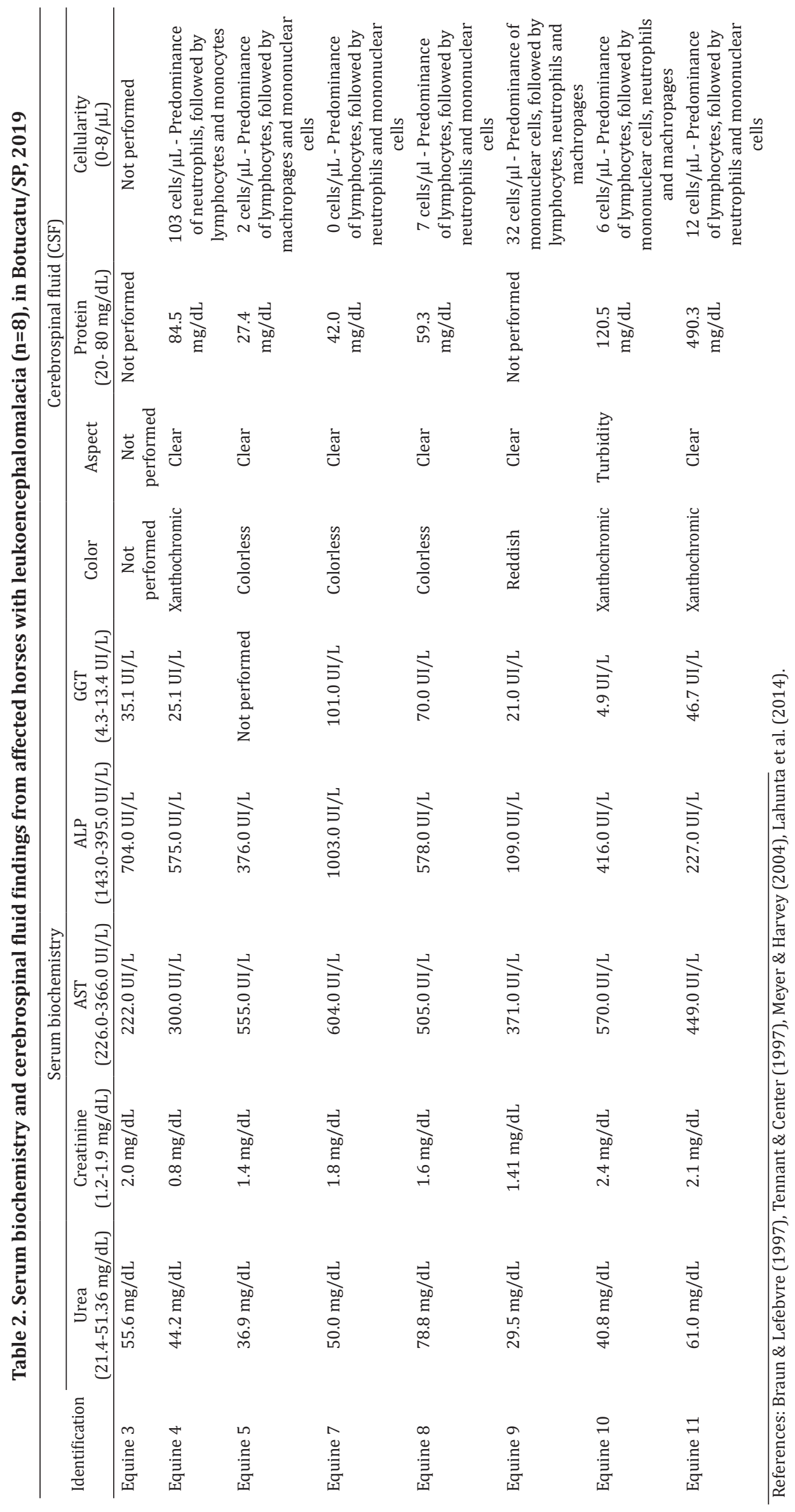

Pesq. Vet. Bras. 41:e06912, 2021 
The clinical signs observed in our study were similar to those observed by other authors (Riet-Correa et al. 1998, Pimentel et al. 2009, Del Fava et al. 2010, Vendruscolo et al. 2016). The time of disease evolution before the animals were admitted to the veterinary hospital varied from 1 to 4 days (average 2.5 days) and from 1 to 16 days (average 8.5 days) till death after admission to the veterinary hospital. This is in agreement with the observation in previous studies (Riet-Correa et al. 1998, Pimentel et al. 2009, Del Fava et al. 2010, Vendruscolo et al. 2016), where the time of disease evolution and death of the animals was $2-72 \mathrm{~h}$ and $6-24 \mathrm{~h}$, respectively. Support therapies with fluids, corticosteroids, thiamine, tocopherol, and sedatives (acepromazine and diazepam) were administered to the affected animals in this study, presenting clinical improvement in 18\% (2/11) of the cases, contradicting the indications and findings of Mackay \& Van Metre (2015), where early euthanasia is indicated since specific treatment is not available and none of the treatments is likely to be effective. We believe that mild cases of LEM, with limited extension of brain injuries that do not cause irreversible damage to the central nervous system, can explain the response to the established treatment in our study.

The affected animals showed neurological signs compatible with cerebral and/or brainstem injury, which was also reported by Del Fava et al. (2010). Equine 9 was the only asinine diagnosed with LEM in this study. It presented clinical signs related to brainstem injury, as reported by Del Fava et al. (2010). Two other asinine, that belonged to the same propriety of Equine 7 and 8, had access to contaminated food and had no neurological signs, unlike the ten other horses in the propriety. This suggests and reinforces that this species can resist fumonisin toxicity and predominantly showed only signs of brainstem injury.

In the mycotoxicological analysis, the presence of FB1 in five samples and FB2 in four was observed (Fig.8), emphasizing that FB1 is probably the mycotoxin that causes the disease, as suggested by some authors (Mallmann et al. 1999, StockmannJuvala \& Savolainen 2008, Mackay e Van Metre 2015). FB1 concentrations found in the food offered to Equine 5 (Fig.8) were below those cited by the authors in their studies (Mackay \& Van Metre 2015). However, they are similar to the values reported by Vendruscolo et al. (2016). Thus, we can suggest that the concentration of fumonisins in the food varies and that the sample sent for analysis may not be representative of the concentration in the feed and the levels of toxin ingested by the animal. However, we are not confirming or denying that the values found by the authors can predispose or not to the occurrence of the disease. Nonetheless, we must also take into account an individual's tolerance to mycotoxin, as suggested by Mallmann et al. (1999).

No alterations were observed in the complete blood cell count of the animals. However, serum biochemistry revealed elevated enzyme activity for AST in 75\% (6/8) of cases, ALP in $87.5 \%$ (7/8), and GGT in 85.7\% (6/7), as well as elevated concentrations of urea and creatinine in $37.5 \%(3 / 8)$ and $37.5 \%$ (3/8), respectively (Table 2 ). This reinforces the fact that the liver and kidneys are also targets for fumonisins, as suggested by Minami et al. (2004), Câmara et al. (2008) and Mackay \& Van Metre (2015).

In our study, the CSF findings from animals affected by LEM revealed xanthochromia (43\%; 3/7), turbidity (14\%; 1/7), hyperproteinorrachia (50\%; 3/6), and mixed pleocytosis (43\%; $3 / 7$ ) (Table 2), contradicting the findings of Mackay \& Van Metre (2015), which reported that only hyperproteinorrachia is observed in CSF of equids affected by LEM. These findings can also be observed in other diseases that affect the central nervous system, such as equine herpesvirus myeloencephalopathy, where CSF shows xanthochromia and hyperproteinorrachia. In equine protozoal myeloencephalitis, CSF presents with hyperproteinorrachia and pleocytosis. Meanwhile, in West Nile encephalitis, CSF presents with pleocytosis with a predominance of lymphocytes. In rabies, the CSF is normal or present with pleocytosis with a predominance of mononuclear cells and hyperproteinorrachia and others (Mackay \& Van Metre 2015). Therefore, these are essential for differential diagnosis, as previously reported (Riet-Correa et al. 1998, Del Fava et al. 2010). Besides that, CSF can not show any alteration in cases of LEM, which has been observed in three cases $(43 \% ; 3 / 7)$ in this study, emphasizing the importance of mycotoxicological analysis and a post-mortem exam as part of the diagnosis of LEM.

\section{CONCLUSION}

The affected animals showed neurological signs that were compatible with cerebral and/or brainstem injuries. The cerebrospinal fluid (CSF) from animals with leukoencephalomalacia (LEM) may present with xanthochromia, hyperproteinorrachia, and pleocytosis, reinforcing that this disease should be included in the differential diagnosis of encephalomyelopathies.

Acknowledgments.- This study was supported by the Veterinary Hospital of the "Faculdade de Medicina e Zootecnia”, "Universidade Estadual Paulista Júlio de Mesquita Filho" (FMVZ-Unesp), Botucatu/SP.

Conflict of interest statement.- The authors declare that there are no conflicts of interest.

\section{REFERENCES}

Bando E., Gonçales L.N., Tamura N.K. \& Machinski Junior M. 2007. Biomarcadores para avaliação da exposição humana às micotoxinas. J. Bras. Patol. Med. Lab. 43(3):175-180.<https://dx.doi.org/10.1590/S1676-24442007000300006>

Braun J.P. \& Lefebvre H.P. 1997. Kidney function and damage, p.485-528. In: Kaneko J.J., Harvey J.W. \& Bruss M.L. (Eds), Clinical Biochemistry of Domestic Animals. 6th ed. Academic Press, Massachusetts.

Câmara A.C.L., Afonso J.A.B., Riet-Correa F., Mendonça C.L., Dantas A.F.M., Costa N.A., Dantas A.C., Costa Neto H.A., Campos A.G.S.S. \& Souza M.I. 2008. Leucoencefalomalácia em equídeos no estado de Pernambuco. Ciênc. Anim. Bras. 9(2):470-479. <https://dx.doi.org/10.5216/cab.v9i2.1222>

Del Fava C., Lara M.C.C.S.H., Villalobos E.M.C., Nassar A.F.C., Cabral A.D., Torelli C.S., Cunha M.S. \& Cunha E.M.S. 2010. Ocorrência de leucoencefalomalácia (LEME) em equídeos no estado de São Paulo, Brasil: achados anatomopatológicos. Braz. J. Vet Res. Anim. Sci. 47(6):488-494. <https://dx.doi.org/10.11606/ issn.1678-4456.bjvras.2010.26812>

Lahunta A., Glass E. \& Kent M. 2014. Cerebrospinal fluid and hydrocephalus, p.78-101. In: Ibid. (Eds), Veterinary Neuroanatomy and Clinical Neurology. 4 th ed. Elsevier, Missouri.

Mackay R.J. \& Van Metre D.C. 2015. Diseases of the nervous system, p.917-1014. In: Smith B.P. (Ed.), Large Animal Internal Medicine. 5th ed. Elsevier, Missouri.

Mallmann A.O., Santurio J.M. \& Dilkin P. 1999. Equine leukoencephalomalacia associated with ingestion of corn contaminated with fumonisin B1. Revta Microbiol. 30(3):249-252. <https://dx.doi.org/10.1590/S000137141999000300011> 
Meyer D.J. \& Harvey J. 2004. Clinical chemistry, p.145-155. In: Ibid. (Eds), Veterinary Laboratory Medicine: interpretation and diagnosis. 3rd ed. Elsevier, Missouri.

Minami L., Meirelles P.G., Hirooka E.Y. \& Ono E.Y.S. 2004. Fumonisinas: efeitos toxicológicos, mecanismos de ação e biomarcadores para avaliação da exposição. Semina, Ciênc. Agrár. 25(3):207-224. <https://dx.doi. org/10.5433/1679-0359.2004v25n3p207>

Pimentel L.A., Oliveira D.M., Galiza G.J.N., Rego R.O., Dantas A.F.M. \& RietCorrea F. 2009. Doenças do sistema nervoso central de equídeos no semi-árido. Pesq. Vet. Bras. 29(7):589-597.<https://dx.doi.org/10.1590/ S0100-736X2009000700015>

Reis-Gomes A., Marcolongo-Pereira C., Sallis E.S.V., Bruhn F.R.P., Faria R.O., Schild A.L. \& Meireles M.C.A. 2018. Epidemiologia de micoses, pitiose e micotoxicoses em equinos no sudeste do Rio Grande do Sul. Pesq. Vet. Bras. 38(6):1110-1116. <https://dx.doi.org/10.1590/1678-5150-PVB-5182>

Riet-Correa F., Rivero R., Odriozola E., Adrien M.L., Medeiros R.M. \& Schild A.L. 2013. Mycotoxicoses of ruminants and horses. J. Vet. Diagn. Invest. 25(6):692-708. <https://dx.doi.org/10.1177/1040638713504572> $<$ PMid:24091682>
Riet-Correa F., Soares M.P. \& Mendez M.C. 1998. Intoxicações em equinos no Brasil. Ciência Rural 28(4):715-722. <https://dx.doi.org/10.1590/ S0103-84781998000400029>

Salles-Gomes T.L., Almeida P.E., Moreira M., Canola J.C., Canola P.A. \& Souza A.H. 2003. Surto de Leuconcenfalomalácia equina provocada por ração comercial com concentração de fumonisina inferior a $10 \mathrm{ppm}$. Ars Vet. 19(3):267-271

Santos C.E.P., Souto F.S.M., Santurio J.M. \& Marques L.C. 2013. Leucoencefalomalácia em equídeos na região Leste de Mato Grosso. Acta Scient. Vet. 41:1119.

Stockmann-Juvala H. \& Savolainen K. 2008. A review of the toxic effects and mechanisms of action of fumonisin B1. Human Exp. Toxicol. 27(11):799-809. <https://dx.doi.org/10.1177/0960327108099525><PMid:19244287>

Tennant B.C. \& Center S.A. 1997. Hepatic function, p.379-412. In: Kaneko J.J., Harvey J.W. \& Bruss M.L. (Eds), Clinical Biochemistry of Domestic Animals. 6th ed. Academic Press, Massachusetts.

Vendruscolo C.P., Frias N.C., De Carvalho C.B., De Sá L.R.M., Belli C.B. \& Baccarin R.Y.A. 2016. Leukoencephalomalacia outbreak in horses due to consumption of contaminated hay. J. Vet. Intern. Med. 30(6):1879-1881. <https://dx.doi.org/10.1111/jvim.14588> <PMid:27744651> 